\title{
3 Brothers and Rebels
}

\author{
Mursi's legitimacy crisis, popular grievances, and the \\ Tamarod protest coalition
}

\begin{abstract}
This chapter retraces the lead-up to the Tamarod uprising on June 30, 2013, and the ouster of President Mursi. It illustrates how the "quiet entente" between the army and the Muslim Brotherhood, the two most powerful organized players in post-Mubarak Egypt, had tarnished the new president's image from the start. The conflicted interactions between his administration and an alliance of opposition players during a phase of rapid political transition cemented the image of an Islamist president who attempted to monopolize his grip on power. In this context, a new powerful player emerged in the shape of the Tamarod campaign. Its performative disruption of the status quo through mass protest on June 30 brought the government crisis to the fore and paved the way for a military coup.
\end{abstract}

Keywords: Mursi, Tahrir Square, Tamarod, military coup, revolution, Islamism

Mohamed Mursi's presidential oath set the stage for conflict. The formal installation of Egypt's first civilian president was scheduled for June 30, 2012. But on the day before his formal oath of office, the Muslim Brotherhood and its political arm, the Freedom and Justice Party (FJP), organized an informal inauguration ceremony on Tahrir Square. There, Mursi stood defiantly before his followers and declared from a podium the conclusion of the tumultuous revolutionary period and the beginning of a new, democratic era in Egypt. ${ }^{1}$ Accompanied by frantic cheers from the crowd, many of whom hailed from the once-banned Islamist Muslim Brotherhood, the president-elect unbuttoned his jacket to prove that he was speaking without a protective vest.

1 For a full record of the speech see https://www.youtube.com/watch?v=LGoxgvkcLYo.

Grimm, Jannis Julien, Contested Legitimacies: Repression and Revolt in Post-Revolutionary Egypt. Amsterdam: Amsterdam University Press 2022 DOI: 10.5117/9789463722650_CHO3 
Then he went on to read the official oath of office: I swear by God that I will sincerely protect the republican system and that I respect the constitution and the rule of law. [...] I will look after the interests of the people and protect the independence of the nation and the safety of its territory." On the next day, Mursi repeated his oath to the 17 Mubarak-appointed judges of the Supreme Constitutional Court (SCC).

Mursi's popular oath on Tahrir Square was widely perceived as a message of defiance to the Supreme Council of Armed Forces (SCAF) that, thus far, had steered the fate of the republic since the ouster of Husni Mubarak. It was also a clear nod to those who were demanding restitution of popular sovereignty. Traditionally, the Egyptian President is sworn in at the Parliament. The logical site for the presidential inauguration would thus have been the Majlis al-Sha'ab, the People's Assembly. In the last parliamentary elections in January and February 2012, the FJP had secured a sweeping majority in this assembly. But the lower house had been dissolved shortly before Mursi's inauguration. Faced with the prospect of the Muslim Brotherhood and its FJP dominating all major institutions within Egypt's constitutional architecture, the then-ruling SCAF had asked the Supreme Court to disband the house, based on alleged faults in Egypt's electoral procedures. The upper house, the so-called Shura Council, which had been elected based on the same faulty electoral law, faced similar legal challenges.

Against this backdrop, Mursi's informal oath in Midan Tahrir marked, if not a legal, then at least a symbolic challenge to the SCAF's guardianship over the transition process. This test of the army's resolve alarmed those who had seen the dissolution of the Parliament a necessary attempt by the military and the judiciary to provide checks and balances to the Brotherhood's sweeping takeover of Egypt's governing institutions - an alleged akhwana [Brotherhoodization] of the Egyptian state (Haenni, 2016, pp. 28-30). The newly elected president's first moves further nourished their fears: Merely a week in office, on July 9, 2012, Mursi decreed that the dissolution of the Shura Council was not legal and asked it to convene in its original composition. He furthermore entrusted the council with a parliamentary caretaker function until a new constitution would pave the way for a fresh round of elections.

While short-lived in their immediate effect - shortly after, another SCC ruling overturned the president's decree - the mark left on the Mursi's public image by the popular oath and his defiance of the judges was longerlasting. For Mursi's opponents, both actions represented bold attempts of the president to place himself above the judiciary. They also exemplified the new president's priorities: His policies targeted not primarily those who had driven the country to the brink of civil strife, the feloul [remnants] of 
the old regime. Instead, they aimed to disempower those who could curb the Brotherhood's influence on the country's transition.

\section{The Polarization of Egyptian Society}

A range of symbolic steps may be read as attempts by the new president to counter and eradicate this narrative and position himself as a legitimate representative of the revolutionary and democratic forces. Shortly after taking office, Mursi established two committees in charge of overseeing transitional justice measures. One committee was tasked with examining all cases of civilians tried in military courts after the revolution, whose number had surpassed 12,00o by the end of 2011. A second fact-finding committee was tasked with investigating the killing of unarmed protesters during the 18 days of Tahrir and the ensuing rule of the SCAF.

Mursi also moved quickly to answer the calls of the popular campaign No to Military Trials, a coalition of revolutionary youth groups, human rights advocates, and leftist and liberal political parties, for releasing those who had been detained in the course of the January 25 Revolution and the months after under the rule of the SCAF. On July 19, 2012, 572 political detainees were released and cleared of their indictments as part of a Ramadan amnesty. Moreover, a range of old-guard figureheads was sent into forced retirement. Amongst those replaced on August 5, 2012, was the head of the military police, General Hamdy Badeen, as well as the notorious intelligence chief Mourad Mouwafi, who had been appointed and served in his position under Mubarak. The replacements were officially framed as the consequence of a security lapse that had enabled a deadly jihadist assault on Egyptian troops near Rafah on August 5, 2012. But since most of the dismissed officers were hardly involved in decisions about troop movements in Sinai, they were widely interpreted as an attempt by the president to purge the security sector from the confidants of the Mubarak regime (S. A. Cook, 2012; Fahim, 2012).

The purges in the domestic security establishment were soon followed by a reshuffle of the military leadership, in defiance of a SCAF decree that had stripped authority over military personnel from the presidency. On August 12, 2012, both Defense Minister and SCAF head Field Marshal Mohammed Hussein Tantawi and the Army Chief of Staff Sami Anan were asked to resign. Tantawi and Anan represented the two highest-ranking officers in the Supreme Council of Armed Forces. They had also been the public faces of the army throughout the entire transitional period since the fall of Mubarak. Later in Autumn, Mursi additionally ordered retrials 
for former President Mubarak and his Minister of Interior Habib al-Adly, stripping them of their double jeopardy protection.

However, this entire transitional justice process was plagued by allegations of politicization and victors' justice. Most measures were implemented selectively and largely spared members of the armed forces (Van Leuven, 2014). First, the fact-finding committee comprised not only judges, lawyers, and various prominent public figures, but also the assistant minister of interior, a military general, and an officer of Egypt's intelligence apparatus. By contrast, six relatives of slain or injured protesters were appointed as observers only. The doubts cast by its composition on the committee's independence were reinforced by its final report, which remained classified after its completion in December 2012. According to leaked excerpts, the 700-page document implicated the military in incidents of torture, death in detention, and forced disappearances (Hill \& Mansour, 2013). However, the full text was never made public but referred to the prosecution as a classified document. It remains there until today. Tellingly, Mursi's new expanded list of defendants in the retrial of the killings during the January 25 Revolution did not include any military officers either.

This selective enforcement of transitional justice nourished suspicions that the Muslim Brotherhood and President Mursi were colluding with the military. Even the political pardons did not sway this image. Those who portrayed Mursi as an Islamist wolf in sheep's clothing dismissed them as revolutionary window-dressing. The pardons furthermore cemented the image of a president intent on collaboration with the old guard to guarantee privileges for his supporters (Shenker, 2016, p. 259). After all, the first of a total of nine presidential pardons, granted by Mursi on July 26, 2012, went exclusively to Islamist convicts. The list included senior Brotherhood leaders residing abroad who had been tried in absentia as well as 18 presumed veterans of the Gama'a al-Islamiya's armed Islamist insurgency of the 1980 s and 1990s. Some of the latter had received death sentences from state security courts for their involvement in an assassination attempt against Husni Mubarak in Addis Ababa. Only much later, on the $100^{\text {th }}$ day of his presidency, Mursi issued a general pardon for all citizens arrested for protesting since January 25, 2011.

In truth, the number of Islamists released during Mursi's rule was small (27) compared to the more than 800 released members of Islamist or jihadist organizations during the rule of the SCAF in 2012 (Bahgat, 2014). Nevertheless, misinformation and leaked statements by senior officers construed the image of a president who favored, above all, his ideological kin and who had irresponsibly pardoned dangerous convicted extremists. These accusations 
thwarted the president's attempts to portray himself as receptive to the goals of the January 25 Revolution. Instead, they reinforced the narrative that the Muslim Brotherhood and its representatives "preferred to deal and bargain with the deep state; that is, it worked through traditional channels such as the military and the Ministry of Interior, rather than accommodating and allying with the young revolutionaries and activists who sparked the uprising" (Al-Anani, 2015a, p. 535).

\section{The Shadow of the "Quiet Entente"}

Notably, the narrative of a tacit coalition between the Islamists and the officers resulted from the early post-revolutionary interactions among Egypt's key political players. Above all, the Muslim Brotherhood's initial hesitance to join the 2011 Tahrir protests against Husni Mubarak cast a long shadow on its revolutionary credentials. ${ }^{2}$ This was despite the subsequent contribution of Islamist demonstrators in making the 18 days of Tahrir successful with the help of the organization's logistical infrastructure and by providing dedicated protection units to the occupiers. Having the most to lose, as the experience of violent oppression of Islamists during the past decades had proven (see Pargeter, 2010; Wickham, 2013), the organization's Guidance Bureau had initially warned of the disruptive and destabilizing potential of a popular revolt (Muslim Brotherhood, 2011).

Only after witnessing how the demonstrators successfully claimed Midan Tahrir as their site of representation, they re-evaluated the stakes in the ongoing conflict and decided to join the rallying calls for a Friday of Anger on January 27, 2011. Up to 100,000 Muslim Brotherhood members participated in the subsequent countrywide protests (Wickham, 2013, p. 162), which constituted the turning point for the uprising against Mubarak (Harders \& König, 2013, p. 27). Nevertheless, the Brotherhood's initial rejection of the protests and hesitant support for the uprising had left a mark.

This badge of shame was reinvigorated by the organization's pragmatic decision to demobilize its constituents, shortly after Mubarak's ouster on

2 Young Brotherhood members had been at the forefront of the Tahrir protests since January 25 . Some Brotherhood youth activists had also been active in the planning phase of the protests. During two visits to Midan Tahrir on January 25 and 26, I spoke with several young Brothers who had taken to Tahrir jointly with fellow members of the Zamalek soccer fan club. These Ultras would soon gain notoriety for their physical defense of the Tahrir sit-ins against police incursions and attacks by state-hired thugs. The Brotherhood's guidance bureau tolerated this level of individual participation but remained hesitant to endorse the uprising against Mubarak (Interview with former Brotherhood member, Istanbul, November 12, 2017). 
February 11, 2011, and embrace dialogue with the remnants of his regime. After the downfall of Mubarak's National Democratic Party (NDP), the Brotherhood and its newly founded political arm, the nominally independent but factually subordinated Freedom and Justice Party (FJP), ${ }^{3}$ became the strongest organized player in Egypt's post-revolutionary arena. In the subsequent months, they took a conciliatory stance vis-à-vis the ruling SCAF. With the newly founded Salafist Nour-Party, first, they supported the SCAF's constitutional referendum. Then, they neglected calls from most smaller opposition factions for a postponement of parliamentary elections considering the prospects of easy electoral victories. This nonconfrontational and accommodative stance - discussed as a "quiet entente" between Brotherhood and army (see Al-Anani, 2015a) - characterized the Muslim Brotherhood's strategy throughout the entire transition period. It also tainted the new President's revolutionary credentials.

Even Mursi's far-reaching purge of security sector officials was not able to rehabilitate this public image. Praised by spontaneous crowds on Midan Tahrir as a de facto end to military rule in Egypt, the sacking of the SCAF leaders, in addition to the leadership of several army branches, was not unambiguous. It left the military's privileges intact, including the right to prosecute civilians in military courts. Furthermore, it provided those responsible for crimes and massacres during the SCAF rule with a safe exit and amnesty from legal prosecution (Achcar, 2013, p. 272ff.). When leaving office, Hussein Tantawi was fittingly honored by Mursi with Egypt's highest state medal, the Order of the Nile. The former SCAF chairman and his chief of staff were also awarded posts as presidential advisors.

Moreover, their positions were filled with officers who enjoyed even deeper support from within military ranks. Tantawi and Anan were intimately connected to the former Mubarak regime and, thus, resented by other leading army officers as magnets of public criticism. In contrast, the new Defense Minister Abdel Fattah al-Sisi and Chief of Staff Sedki Sobhi hailed from a new generation of army leaders. Untainted by the hands of the former regime, they provided the military with the opportunity for a fresh

3 From its foundation, the FJP encompassed countless Egyptians who did not belong to the group. Formal membership in the Brotherhood requires an intensive training process, known as tarbiya, including a five-to-eight yearlong gradual ascendency from an initial status as a prospective member (for a description of this incubation process see Al-Anani, 2016, pp. 82-98). Becoming an FJP member was substantially easier. The party thus became a mechanism for extending the boundaries of the populace under the clout of the Brotherhood, while maintaining the rigid internal structures that had ensured the MB's coherence and resilience over decades of repression. 
start and a chance to whitewash its political image. The new appointments also allowed the military to restore its prestige as an impartial protector of the nation, above factional politics. From his first commission as an officer in 1977, above all, Al-Sisi had mainly stuck to a traditional military career path while advancing through the ranks of Egypt's mechanized infantry. Only in 2010, he assumed a more political role through his appointment to the post of director of military intelligence, after serving a stint as its deputy director. In this capacity, he joined the SCAF as the council's youngest member, where he served as the liaison officer between the armed forces and Egypt's political parties. Accordingly, the SCAF reshuffle represented an entrenchment of the status quo, rather than a step towards civilian governance.

Mursi's image as a reformer indebted to the spirit of the revolution was further undermined by his appointment of Major General Mohamed Ibrahim, a former assistant minister in the prisons department, as minister of interior. Ibrahim replaced Ahmed Gamal El-Din, who had come under criticism for his role as deputy minister for general security during the deadly Mohamed Mahmoud clashes in November 2011. Like Tantawi's retirement, this cabinet reshuffle was intended to signal a fresh start. However, with Ibrahim - an old hand of the Mubarak regime - taking office, it appeared as a return to the old days.

\section{Mursi's Constitutional Declaration as a Watershed}

These ambivalent actions severely damaged Mursi's legitimacy from his early days. The breaking point came with a fierce battle between the presidency and the Egyptian judiciary. This conflict culminated on November 22, when Mursi issued a controversial constitutional declaration that shielded him from judicial interference and effectively put the executive beyond the supervision and control of the judiciary. The decree aimed to end the legal battle over the appointment of a new prosecutor-general as well as the ongoing struggle between the Mursi administration and leading opposition members over the composition of the Constitutional Assembly: The newly instated assembly had been exclusively appointed by the Brotherhooddominated upper house and included many prominent Islamists. This raised fears within the liberal camp that the constitutional drafting process if left unchecked, would produce the foundations for a theocratic regime. As the dialogue between Mursi and opposition leaders stalled, the risk increased that the way the assembly had been elected could be ruled illegal in court. Mursi's constitutional declaration prevented this by shielding not only the 
presidency but also the Constitutional Assembly and the lower house of parliament from potential judicial interference and dissolution.

Mursi attempted to hedge his bets by introducing a transitional justice passage into his declaration, which intended to pave the way for retrials of all defendants accused of harming protesters during 2011. Moreover, he made the first use of his new legislative powers by dismissing the Mubarak-appointed Prosecutor General Abdel Meguid Mahmoud. But rather than placating the opposition, the declaration antagonized not only the political opposition but also members of the administration and the usually supine elite. Regardless of any potential rationales for the constitutional declaration (N. J. Brown, 2013, p. 49), ${ }^{4}$ the disempowerment of the judiciary by the executive soon came to symbolize the frontier in a struggle for interpretive predominance over the country's democratic transition. Consequently, it became the reference point for tumultuous disputes over the meanings of constitutionality, the separation of powers, sovereignty, and democratic legitimacy. Several public figures who had been appointed by Mursi as presidential advisors resigned and large sections of the Egyptian public took to the street in what quickly turned into nationwide protests.

Popular anger at Mursi overstepping his institutional boundaries manifested most visibly in a series of protests in front of the Ittihadiya presidential palace on December 5, 2012. These protests were organized by the so-called National Salvation Front (NSF). This loose alliance of the main opposition parties and several revolutionary youth movements threw the growing dissent into sharp relief. According to Zaid Eyadat (2015, p. 169), the structure of the NSF mirrored the decentralized resistance against authoritarian encroachment witnessed during the January 25 Revolution. Above all, it illustrated how Mursi's divisive policies had led to the emergence of a new dominant antagonism in Egypt's protest arena which effectively blurred the formerly salient divisions that had fragmented Egypt's opposition in the aftermath of 2011. The NSF did not forward any positive vision for better governance (Dworkin, 2013, pp. 6, 20). However, the coalition included players of every political stripe who were bound together by their shared

4 Several analysts, including law professors Noah Feldman (2012) and Mohammad Fadel (2014), have defended Mursi's decree as well-intentioned, albeit miscommunicated. They argue that a failure to issue the decree would have led to the collapse of the entire transition process by jeopardizing the near-completion of the draft constitution and thus preventing parliamentary elections. Without the decree, accordingly, Egypt would have returned to de facto indirect military rule. Their reasoning, however, reveals a purely legalist view of democratic transitions. Whether Mursi's policies were "legitimate" or not, depended not on legal arguments but popular perception. 
opposition to Mursi. Its initial 35 members comprised liberals and socialists, but also several centrist and reactionary parties that were populated by old regime elites. ${ }^{5}$

When these groups converged at the presidential palace to demand Mursi's resignation, police forces collectively disobeyed Mursi's orders to step in. As the crowds grew larger, they were confronted, instead, by civilians, armed with sticks and chains, who had been mobilized by the Muslim Brotherhood to disperse the protests and protect the seat of the presidency. The ensuing fervent clashes between both camps resulted in a dozen casualties and hundreds of injured on both sides.

The Ittihadiya clashes became a transformative event for Egypt's postrevolutionary dynamics. They set the stage for a return of violence to Egypt's streets. For the first time since the 2011 uprising, deadly violence was not only deployed by police forces or hired thugs against civilians but developed in a confrontation between Egyptians and their fellow citizens: at the presidential palace, pro- and anti-Mursi demonstrators clashed in brutal melees; across Egypt's provinces, angry mobs set FJP party offices and Brotherhood branch offices ablaze.

More importantly, the clashes polarized the already fragmented Egyptian public into two camps, with each defending a partisan notion of legitimacy and democratic due process. This dichotomization of the public sphere laid path dependencies for how different players would support, defend, fight, or come to terms with the "coup-volution" (Hamada, 2014, p. 37) that would soon sweep Mursi from office. Ittihadiya thus became a catalyst for the emergence of two competing compound players in Egypt's post-revolutionary scene:

On the one hand, the Muslim Brotherhood's decision to systematically engage in street politics through a mobilizing mechanism can be traced back to the experience of Ittihadiya (Ketchley, 2017a, p. 135). The clashes left eight members of the group dead. The security forces had stood by and watched Muslim Brothers being chased through Cairo's streets without intervening. Consequently, the Brotherhood decided that hereafter, it would confront all protests directed against their president with counter-demonstrations.

5 Initially, it comprised 35 political parties and revolutionary groups, with the April 6 Youth Movement, the National Progressive Unionist Party, the Dignity Party, the Socialist Popular Alliance, the Social Peace Party, the Egyptian Communist Party, the Egyptian Popular Current, and the Maspero Youth Coalition occupying the left-wing; the Kefaya Movement, the National Association for Change, the Reform and Development Misruna Party, the Social Democratic Party and the Constitution Party taking the liberal wing; the New Wafd and the Free Egyptians representing the centrist currents; and the Freedom Party and the Amr Moussa's Conference Party occupying the right-wing. 
Dedicated protection units within the lower Brotherhood ranks were charged with the protection of street protests against opponent attacks and, potentially, against the police should it side with the former. ${ }^{6}$

On the other hand, the Brotherhood's deployment of armed troops to disperse the protests also galvanized support for the coalition against Mursi's presidency as it confirmed the reproaches that the Brotherhood and its president were placing themselves above the law. As a participant of the Ittihadiya protests in December recalls: "The massacre of Ittihadiya revealed the Brotherhood's true face. They could no longer hide their bloody hands. [...] The Central Security Forces [Egypt's notorious riot police] did nothing to defend us, so we had to defend ourselves." ${ }^{7}$

Mursi did little to counteract this impression. On the contrary, his rush to complete and pass the new constitution through a popular referendum on December 15, 2012, further alienated his critics who felt dismayed that the Islamists had monopolized the drafting process and produced a document that cemented the status quo. Following several resignations from the Constitutional Assembly as well as boycotts from underrepresented liberals, the draft constitution was finalized by an exclusively Islamist body. None of the oppositional players who had rallied for the Ittihadiya protests felt ownership over the proposed document.

\section{Rebellion against Mursi}

The aftermath of Ittihadiya witnessed a loss of appetite for further violent agitation. The brutal clashes left a mark on the public mood, and further instances of major political violence remained absent during the remainder of Mursi's tenure until the protests of June 30, 2013. Dissent within the security apparatus grew, nonetheless. Additionally, the socio-economic crisis propelled discord to new heights, fueled by violent repression on the anniversary of January 25, 2011. This violence served to catalyze street politics: By April 2013, youth groups launched a grassroots campaign to collect signatures for the resignation of Mohamed Mursi, a revocation of the 2012 constitution, and a temporary return to the 1971 constitution pending the drafting of a more inclusive constitutional document. The idea of the campaign, which gave itself the name Tamarod [Rebellion], was to gather and submit 15 million signatures to the constitutional court on the anniversary of 
Mursi's assumption of Egypt's presidency. This way it attempted to assemble a critical quorum that quantitatively surpassed the 13 million votes by which Mursi had won the election. A petition in colloquial Arabic was distributed across the country and declared the goals of the campaign:

Because security has not been restored since the 2011 revolution... we do not want you

Because the poor still have no place... we do not want you

Because we are still begging for loans from abroad... we do not want you Because there is no justice for the martyrs... we do not want you Because there is no dignity for me and my country... we do not want you Because the economy has collapsed and depends only on begging... we do not want you

Because Egypt is still following the footsteps of the USA... we do not want you

The petition also assigned responsibility to the president for the country's misery. The lack of physical and social security was held up as proof of his lack of suitability for office. Signatories declared that they were of sound mind and demanded the destitution of President Mursi as well as early presidential elections.

Tamarod adopted this modus operandi from the prominent opposition leader Mohamed El-Baradei who had championed a popular petition for constitutional reforms in February 2010 (see Elyachar, 2014). His sevenpoint list of demands was mirrored by Tamarod's sevenfold justification for rejecting Mursi. However, in contrast to El-Baradei who had spent "more time outside of Egypt in 2009-10 than he did within the country" (Kamrava, 2014, p. 268), the Tamarod campaign drew from the experience of community advocacy groups such as Askar Kazeboon [The military are liars] and maintained a firm grassroots infrastructure throughout the country (Alexander \& Aouragh, 2014, pp. 902-903). This way, it avoided the mistakes of revolutionary youth groups in 2011, whose mobilization had been heavily focused on social media and blogs.

At first, the group was hardly taken seriously. Most of its members knew one another from Kefaya [Enough!], a grassroots campaign that had once mobilized against the re-election of former President Husni Mubarak. But the leaders of the campaign, the activists Mohammed Abdel Aziz, Mahmoud Badr, Moheb Doss, Walid El-Masry, and Hassan Shahin were hardly known. Once the signature campaign gathered pace in the countryside, it nevertheless garnered the attention of prominent players, such as the domestic 
security services and the Ministry of Interior. Over the ensuing weeks, the Tamarod initiative was provided with logistical and financial support from different players within the ranks of state security (see Ketchley, 2017b; Springborg, 2018) and rhetorical backing by prominent opposition leaders: "Ministry officials and police officers helped collect signatures for the petition, helped distribute the petitions, signed the petition themselves, and joined the protests" (Alsharif \& Saleh, 2013). One of my interviewees, who took part in the initial Tamarod mobilization in the coastal city of Alexandria, recounts how the logistical support of the local police ranged from assistance in printing flyers and petition forms to physical protection of demonstration marches against counter-demonstrations of Mursi supporters. ${ }^{8}$

As a consequence of this intimate connection, several authors have analyzed Tamarod as a creation of the "deep state" to undermine the rule of President Mursi (see Springborg, 2018)..$^{9}$ Others have pointed to the scarcity of reliable non-partisan information about any systematic support for Tamarod by the military, beyond individual shows of solidarity by some of its members (Roll, 2016, p. 33). At any rate, Tamarod's success was not solely due to the state support that it received. Growing hardship and a bottleneck in the supply of cooking gas, car fuel, and basic food staples further catalyzed the movement's growth. In June 2013 queues of cars waiting for diesel at gas stations often stretched for several blocks creating traffic jams and bringing city life to a near standstill. The fuel shortage also manifested in frequent power outages, often several times a day and during peak business hours. Likewise, fuel and foodstuffs experienced massive price hikes. The prices for cooking oil, sugar, and wheat, for instance, increased by half compared to the previous year (Westall \& Perry, 2013).

As the crisis culminated, the official reaction ranged from a deflection of responsibility to outright denial. Even after the head of the Egyptian Gas and Petroleum Company publicly acknowledged that petroleum consumption was exceeding the available stock, the Mursi administration downplayed the situation. As late as June 25, 2013, it continued to deny the existence of a

8 Interview with former Tamarod organizer, London, March 2018.

9 In several interviews, former Tamarod campaign members, including its founding member Moheb Doss, indicate close coordination with several military officers and security agencies throughout the signature campaign. Above all, Badr, Aziz, and Shahin reportedly attended several meetings with the Ministry of Interior and with the then-head of the armed forces Abdel Fattah al-Sisi (Atef \& Frenkel, 2014). Former military and security officers, in turn, served as the intermediaries between the protest organizers within the Tamarod campaign and the armed forces during the preparations for June 30 . 
crisis and, instead, attributed the supply gap to ineffective distribution and misappropriation. Such statements were parroted by government supporters who blamed a covert alliance of former regime cronies for manufacturing the crisis (N. Brown, 2013).

But the deflective attitude also pitted the Mursi administration and its supporters further against those opposing the president. Fueled by growing feelings of insecurity and hardship, above all, in the countryside, Tamarod had grown in strength. By June, the campaign claimed to have gathered a total of 22 million signatures. ${ }^{10}$ Significantly, this count surpassed the number of votes cast for Mursi in the presidential elections. Critics of the government and activists felt empowered by this silent majority. ${ }^{11}$ Consequently, the pace of collective action accelerated until, on June 30, 2013, Egyptians took their protest to Tahrir Square.

\section{The June 30 Uprising}

In the run-up to President Mursi's first year in office, clashes erupted across the country between supporters of the Tamarod campaign and members of the Muslim Brotherhood and its FJP. In reply to Tamarod's protest calls for June 30, the latter had mobilized an "open-ended" sit-in in the capital and called for a nationwide miliuniya [million man march] in defense of Mursi's legitimacy a week before the Tamarod-protest on Tahrir Square. ${ }^{12}$ To avoid further bloodshed and potentially ensuing repression by the security forces, the Brotherhood avoided Tahrir Square which had been claimed by the Tamarod campaign as its main theater. Instead, the pro-Mursi marches were to concentrate on Al-Nahda Square in the district of Giza and on the surroundings of the Rabaa al-Adawiya Mosque in the Cairene suburb of Nasr City.

These protest sites were first announced by a loose coalition of Islamist parties and movements allied with the Brotherhood and its FJP. On June 27,

10 Several polls cast doubt on this signature count. A poll from late May 2013, for instance, indicates that, even when Mursi's approval hit rock bottom at 32 percent, roughly 40 percent of Egyptians had never heard of Tamarod, and only half of those aware of the campaign were amenable to signing it (see Osman, 2013a).

11 Interview with a member of the NSF organizing committee, Berlin/Cairo, June 2014, via Jitsi Meet.

12 The term miliuniya recalls the transformative power of the first million-man march in $21^{\text {st }-c e n t u r y ~ E g y p t ~ o n ~ J a n u a r y ~} 27,2011$, which, as Aoudé (2013) has put it, managed to derail "much of the machinations of the reactionary forces" (p. 249). As a protest tactic, the miliuniya was part of the repertoire of nearly all protest alliances in Egypt since the 2011 uprising, including the Revolutionary Youth Coalition, Tamarod, and the Anti-Coup Alliance. 
2013, this group was officially established as the National Alliance in Support of Legitimacy (NASL, later on, more commonly known as the Anti-Coup Alliance). Besides the Freedom and Justice Party, it comprised more than 40 organizations, ranging from moderate religious movements to ultraconservative Salafi groups. Prominently placed in this alliance were the Building and Development Party - the political arm of the Gama'a al-Islamiya, the Salvation and Development Party - the political arm of the Egyptian Islamic Jihad, the moderate Islamic Wasat [Center], as well as Al-Raya [the Flag], the party of Salafist preacher Hazem Salah Abu Ismail. ${ }^{13}$ Over the coming weeks, the shared experiences of confronting police forces and opponents would forge this loose coalition into an efficient protest alliance.

As the guiding frame for its first joint demonstration, the alliance chose the slogan "Legitimacy is a red line." Like the group's name, this slogan not only underscored the centrality of Mursi as the only legitimate president for the alliance's political position. It also directly referenced Mursi who had claimed in an aggressive speech on June 26 that all constitutional and legal powers had been vested in him as the head of the state - and that his legitimacy exceeded that of any mass mobilization in the streets. Mursi had also underscored that social movements, including revolutionary ones, could no longer provide a mandate to anyone, not even the president, other than through the means defined in the constitution:

Revolutionary legitimacy has a range, limits, and a time, after which nations then move to constitutional legitimacy. We are under this constitutional legitimacy now. Wake up people, we have constitutional legitimacy. We have a constitution, a constitution according to which we can be held accountable. ${ }^{14}$

Delivered to a crowd of supporters in front of the Cairo Stadium, this speech reacted to the military's warning that it would consider intervening should turmoil in Cairo's streets persist. After the NASL had announced

13 The NASL additionally comprised the New Labor Party, the Virtue Party, the Reform Party, the Arab Tawhid Party, the Islamic Party, the Homeland Party, the Asala [Originality] Party, the People's Party, the Coalition of Arab Tribal Union in Egypt, the Revolutionary Trustees Council, the Union of Professional Syndicates (comprising 24 trade unions), the Union of Preachers, the General Union of Farmers of Egypt, the Al-Azhar University Students Union, The Labor Centre, the General Association of Street Vendors, as well as a group of retired officers. See https://www. scribd.com/document/394191292/NASL-Founding-Statement.

14 A speech transcript can be accessed at https://de.scribd.com/document/378807384/ Mursi-Speech-26-June-2013. 
its counter-demonstrations to the Tamarod protests on June 30, Defense Minister Al-Sisi called on all players to reach a settlement through civic dialogue. But he also emphasized the army's constitutional role as guarantor of national security as he spoke in a large auditorium directly to close to a thousand officers. ${ }^{15} \mathrm{His}$ insistence that the armed forces would not "stand by if Egypt descends into violence" was ambiguous enough to be welcomed by all sides. But it was widely understood as an ultimatum to the acting government to compromise and give in to the opposition's demands for change. Empowered by this perceived backing of the armed forces, Egyptians took to the streets on June 30,2013 , in numbers comparable to those of the January 25 uprising. When armored vehicles deployed to Cairo's streets, they were adorned by Tamarod protesters with spray paint slogans that revived the fraternization myth of the January 25 Revolution about the people and the army as "one hand."

Estimates of how many people participated in the June 30 demonstrations vary. ${ }^{16}$ While a military source indicated an estimated turnout of 14 million to Reuters (Fayed \& Saleh, 2013), Tamarod spokesmen were quick to claim that 33 million Egyptians - over one-third of the entire population - had taken to the street. Albeit hardly credible, this count was adopted by the country's major media outlets and made it into international reporting. Regardless of the actual turnout, the demonstrations caused a shift in the balance of power also due to their demographic diversity and social and geographical spread to all corners and classes of the republic. Those who marched on June 30 came "from all walks of life; secular and devout, liberal and leftist, revolutionary and reactionary" (Mogahed, 2013; see also Schielke, 2017, p. 209).

Accordingly, the National Salvation Front styled its first statement on the June 30 protests as Revolutionary Communique No.1. Therein, it declared the victory of the revolutionary movement and underscored that the Egyptian people had affirmed the downfall of the regime of Mohamed Mursi and the Muslim Brotherhood. In light of the massive show of protest, June 30 also witnessed the resignation of ten ministers from Mursi's cabinet. Additionally, several state players openly stated their

15 A partial recording of the speech is available at https://youtu.be/rBBmQry7nc8.

16 For instance, Jack Brown suggests a commensurately lower turnout, based on an evaluation of helicopter shots broadcasted by Egyptian state television. The two biggest gatherings in Cairo may have encompassed less than half a million people (J. Brown, 2013). More generous calculations indicate that between 500,000 and 700,000 protestors could have been on the streets of Cairo and, by extension, a maximum of 3 million could have been protesting throughout the whole of Egypt (S. Ismail, 2013). 
support for the protesters: The police forces announced that they would not stand with the Muslim Brotherhood. The Interior Ministry pledged that its policemen would protect the demonstrators against potential assaults (see El-Rashidi, 2013). And the armed forces, in turn, showed their support by canceling the festivities for the 44th anniversary of the air force, where Mursi was due to speak on the same day. According to Adel Abdel Ghafar (2013), the military also provided the necessary logistics to mediatize the scenes on Tahrir: carried by an army helicopter, an anti-Mursi director was permitted to record aerial shots of the protests which were soon broadcast by Egyptian media.

In addition, different army units paraded their armored vehicles on Midan Tahrir, projected elaborate laser graphics onto the Mogamma administration building, and flew cordons of battle helicopters carrying the Egyptian flag over the heads of the protesters. These spectacles converted Tahrir into the site a carnivalesque celebration of patriotism. As Maged Atef and Sheera Frenkel (2014) recollect:

In the skies above Tahrir Square, military planes began to conduct elaborate flying stunts, painting the colors of the Egyptian flag or drawing hearts in the blue summer sky. The stunts were neither easy to perform nor cheap, but they sent the clear message that both the army and police were behind Tamarod.

Therefore, it came as no surprise when the armed force issued an explicit ultimatum to the president on the following day. Signed by the entire central command of the armed forces, a top brass body of roughly 50 decorated officers, including the SCAF, and read out by a military spokesman on state television, the statement called for the government to meet the people's demands and settle its differences with the opposition within the next 48 hours (see Reuters, 2013). Otherwise, the army would intervene and enact a roadmap for the country's future.

\section{A Crisis of Legitimacy}

With hindsight, it seems obvious that the Tamarod campaign successfully subverted the discourse sustaining Mohamed Mursi's rule. As Seppe Malfait (2014, p. 16) contends, the popular campaign had succeeded in constructing a new narrative, grouped around the contested signifiers of the "revolution," of "democracy," and of "legitimacy." By fixing the meaning 
of these floating signifiers in a discourse that drew a sharp line between the Muslim Brotherhood, on the one hand, and all other elements of Egyptian civil society, on the other, Tamarod's discourse established a new political frontier: To one side were those representing the popular will - including the anti-Mursi demonstrators, oppositional parties and initiatives such as the NSF and Tamarod, as well as key state institutions such as the armed forces and the Ministry of Interior. On the other side of the political divide was the antagonist Other of the incumbent Islamist government and its supporting organizations who, supposedly, were defying this will.

This discourse lionized the Tamarod protesters and aimed to recreate the revolutionary momentum of 2011 where a variegated coalition of state and non-state actors had stood side by side against the authoritarian incumbent regime. It also vilified President Mursi as a peon in the Islamists' larger plan to establish an authoritarian theocracy. Diligent character work was part and parcel of this dichotomizing narrative: From his first day in office, different opposition players had portrayed Mursi as a mere puppet of the Muslim Brotherhood. This caricature was reinforced by subsequent events, such as Mursi's constitutional declaration, which represented just another tile in the larger mosaic of a weak and malevolent president. It became the dominant cognitive scheme for understanding Mursi's actions. Jim Jasper and his co-authors (2020) have aptly described this process of characterization: 'Once a character trait becomes a hook for stories (a 'heuristic' for reporters and the public to understand the world), it is difficult to dislodge it from media discourse" (p. 10).

By the time that the Tamarod campaign filled Tahrir Square, it had undermined President Mursi to such a degree that his claims to democratic legitimation failed to resonate outside of his constituency. Mursi had effectively been portrayed as a minion to the evil villain of the Brotherhood, whose only legitimacy stemmed from a narrow victory in a contentious election - one where the choice for many had been one between two evils [Mursi, an uncharismatic Islamist, on the one side, and Ahmed Shafik, Mubarak's last prime minister, on the other]. This discourse created not only the conditions for an explicit civic alliance against Mursi's rule across the divisions of class, ideology, and movements. It also enabled the formation of an implicit coalition between Mursi's political contenders and the armed forces.

This coalition blurred the hitherto relatively sharp boundaries between state and social players in Egypt's post-revolutionary arena. As a state institution, the military saw its constitutionally guaranteed privileges endangered 
by the prospect of civil strife. Through its support for the Tamarod campaign, it saw a chance to restore its role as a protector of social peace and as a defender of the nation. The powerful "flank effect" (Haines, 2013) created through this integration of variegated players in a political campaign first benefitted mobilization by some of the bloc's members against the precarious status quo and then paved the way for a military coup by others against the first freely elected president Egypt's republican history.

The solidarity of its key allies, but also most Salafi parties and movements (with the notable exception of the Nour Party) as well as other non-religious organizations may have contributed to the Mursi administration's overestimation of its political leeway in the face of credible threats of military intervention and growing momentum for the June 30 demonstrations. Furthermore, the victories at the ballot box since the 2011 uprising - first in the March 2011 referendum on constitutional amendments to the 1971 constitution, then in the December 2011 parliamentary elections, and finally in the presidential elections and constitutional referendum of 2012 - had made the Brotherhood and its president over-confident of their popular backing. As Nicola Pratt (2015) rightly noted:

Indeed, one of the fundamental errors of the Muslim Brotherhood was to assume that their plurality in the first parliamentary elections and their victory in the first presidential elections indicated their hegemony over the vast majority of the population. (p. 46)

In truth, the elections had done little to satisfy popular aspirations for political participation. Hence Mursi met little sympathy when he addressed the nation on June 26,2013 , only to discredit the opposition as reactionary forces and to stress that the ballot box represented the sole legitimate means to gauge the popular will (see Mursi, 2013a).

While media reports indicated growing support for the Tamarod campaign and predicted a massive turnout for the June 30 protests, both President Mohamed Mursi and cadres of the Egyptian Muslim Brotherhood declined not only to bow to the opposition's demands but also rebuffed several mediation offers. In an attempt to mitigate the risk of open conflict and civil strife, among others, the Salafi Nour-Party - the FJP's former coalition partner in parliament - attempted to broker a deal between the Brotherhood and the opposition. However, the armed forces' symbolic deadline passed without an agreement, and without Mursi giving in to the opposition's demands. In the early afternoon of July 3,2013 , the army took sides against the acting government and took over the leadership of the country. 


\section{References}

Abdel Ghaffar, A. (2013, August 7). Egypt's framing wars of June 3oth. OpenDemocracy. http:// www.opendemocracy.net/adel-abdel-ghafar/egypts-framing-wars-of-june-3oth

Achcar, G. (2013). The people want: A radical exploration of the Arab uprising. University of California Press.

Al-Anani, K. (2015). Upended path: The rise and fall of Egypt's Muslim Brotherhood. The Middle East Journal, 69(4), 527-543.

Al-Awadi, H. (2013). Islamists in power: The case of the Muslim Brotherhood in Egypt. Contemporary Arab Affairs, 6(4), 539-551. https://doi.org/10.1080/17550912.2013.856079

Alexander, A., \& Aouragh, M. (2014). Egypt's unfinished revolution: The role of the media revisited. International Journal of Communication, 8, 890-915.

Alsharif, A., \& Saleh, Y. (2013, October 10). Special report: The real force behind Egypt's 'revolution'. Reuters. https://www.reuters.com/article/us-egypt-interior-specialreport/ special-report-the-real-force-behind-egypts-revolution-of-the-state-idUSBRE99908D20131010

Atef, M., \& Frenkel, S. (2014, April 15). How Egypt's rebel movement helped pave the way for a Sisi presidency. BuzzFeed. https://www.buzzfeed.com/sheerafrenkel/how-egypts-rebelmovement-helped-pave-the-way-for-a-sisi-pre

Bahgat, H. (2014, February 16). Who let the jihadis out? Mada Masr. https://www.madamasr.com/ en/2014/02/16/feature/politics/who-let-the-jihadis-out/

Brown, N. (2013, July 17). Egypt's wide state reassembles itself. Foreign Policy. https://foreignpolicy. com/2013/o7/17/egypts-wide-state-reassembles-itself/

Brown, N. J. (2013). Egypt's failed transition. Journal of Democracy, 24(4), 45-58.

Cook, S. A. (2012, August 9). Brother knows best. Foreign Policy. https://foreignpolicy. com/2012/08/og/brother-knows-best/

Dworkin, A. (2013). The struggle for pluralism after the North African revolutions (ECFR Policy Brief No. 74). ECFR. http://www.ecfr.eu/page/-/ECFR74_PLURALISM_REPORT.pdf

El-Rashidi, S. (2013, June 27). Egyptian police divided in run-up to 3 June anti-Morsi rallies. Ahram Online. http://english.ahram.org.eg/NewsContent/1/64/74399/Egypt/Politics-/ Egyptian-police-divided-in-runup-to--June-antiMors.aspx

Elyachar, J. (2014). Upending infrastructure: 'Tamarod', resistance, and agency after the January 25th Revolution in Egypt. History and Anthropology, 25(4), 452-471. https://doi.org/10.1 080/02757206.2014.93046o

Eyadat, Z. (2015). A transition without players: The role of political parties in the Arab revolutions. Democracy and Security, n1(2), 160-175. https://doi.org/10.1080/17419166.2015.1043080

Fahim, K. (2012, August 8). Morsifires intelligence chiefand Sinai governor over soldiers'killings. The New York Times. https://www.nytimes.com/2012/08/og/world/middleeast/egypt-sinaiattacks.html

Fayed, S., \& Saleh, Y. (2013, June 30). Millions flood Egypt's streets to demand Mursi quit. Reuters. https://www.reuters.com/article/us-egypt-protests-idUSBRE95QoNO20130630

Haenni, P. (2016). The reason for the Muslim Brotherhood's failure in power. In B. Rougier \& S. Lacroix (Eds.), Egypt's revolutions: Politics, religion, and social movements (pp. 19-40). Palgrave Macmillan.

Haines, H. H. (2013). Radical flank effects. In D. A. Snow, D. D. Porta, P. G. Klandermans, \& D. McAdam (Eds.), The Wiley-Blackwell encyclopedia of social \& political movements (pp. 10481049). Wiley-Blackwell. https://doi.org/10.1002/9780470674871

Hamada, A. (2014). Understanding the military role in the Egyptian revolution: Comparing February 2011 and July 2013. In N. Belakhdar, I. Eickhof, A. el Khawaga, O. el Khawaga, C. 
Harders, \& S. Sandri (Eds.), Arab revolutions and beyond (pp. 29-40). Center for Middle Eastern and North African Politics.

Harders, C., \& König, C. (2013). Mobilization, repression and coalitions: Understanding the dynamics of the Arab Spring [Discussion Paper]. Center for Middle Eastern and North African Politics. https://www.polsoz.fu-berlin.de/polwiss/forschung/international/vorderer-orient/publikation/working_papers/dp_o6/index.html

Hill, E., \& Mansour, M. (2013, April 10). Egypt's army took part in torture and killings during revolution, report shows. The Guardian. http://www.theguardian.com/world/2013/apr/10/ egypt-army-torture-killings-revolution

Jasper, J. M., Young, M. P., \& Zuern, E. (2020). Public characters: The politics of reputation and blame.

Kamrava, M. (2014). Beyond the Arab Spring: The evolving ruling bargain in the Middle East. Oxford University Press.

Ketchley, N. (2017a). Egypt in a time of revolution: Contentious politics and the Arab Spring. Cambridge University Press.

Ketchley, N. (2017b, July 3). How Egypt's generals used street protests to stage a coup [Washington Post].Monkey Cage. https://www.washingtonpost.com/news/monkey-cage/wp/2017/07/03/ how-egypts-generals-used-street-protests-to-stage-a-coup/

Malfait, S. (2014). An Islamist Caesar in Egypt's passive revolution? A discourse theoretical analysis of Morsi's hegemonic project [Master Thesis in Conflict and Development]. Universiteit Gent.

Mogahed, D. (2013, July 25). Deep runs the divide [Carnegie Endowment for International Peace]. Sada. http://carnegieendowment.org $/$ sada/index.cfm?fa $=$ show\&article $=52493 \&$ solr_hilite $=$

Mursi, M. (2013, June 26). Address to the nation on the anniversary of his inauguration [Arabic, on file].

Muslim Brotherhood. (2011, January 26). Statement from the Muslim Brotherhood regarding the events of January 25 and their aftermath [Arabic]. IkhwanWiki. https://bit.ly/1lıDUj

Pargeter, A. (2010). The Muslim Brotherhood: The burden of tradition. Saqi Books.

Pratt, N. (2015). After the 25 January Revolution: Democracy or authoritarianism in Egypt? In R. Abou-el-Fadl (Ed.), Revolutionary Egypt: Connecting domestic and international struggles. Routledge.

Reuters. (2013, July 1). Egyptian armed forces chief sets ultimatum. https://www.reuters.com/ article/us-egypt-protests-army-text-idUSBRE96014420130701

Roll, S. (2016). Managing change: How Egypt's military leadership shaped the transformation. Mediterranean Politics, 21(1), 23-43. https://doi.org/10.1080/13629395.2015.1081452

Schielke, S. (2017). There will be blood: Expectation and ethics of violence during Egypt's stormy season. Middle East Critique, 26(3), 205-220. https://doi.org/10.1080/19436149.2017.1336023

Shenker, J. (2016). The Egyptians: A radical story. Penguin.

Springborg, R. (2018). Egypt. Polity.

Van Leuven, D. (2014, May 25). Morsi and transitional justice: Peace vs. justice \& implications for a post-Brotherhood Egypt. Al Nakhlah. https://alnakhlah.org/2014/05/25/morsi-and-transitionaljustice-peace-vs-justice-implications-for-a-post-brotherhood-egypt-by-dallin-van-leuven/

Westall, S., \& Perry, T. (2013, March 13). Food price rises put restive Egypt on edge. Reuters. https://www.reuters.com/article/us-egypt-food/food-price-rises-put-restive-egypt-onedge-idUSBRE92CoPW20130313

Wickham, C. R. (2013). The Muslim Brotherhood: Evolution of an Islamist movement. Princeton University Press. 